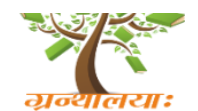

Management

\author{
INTERNATIONAL JOURNAL OF RESEARCH \\ GRANTHAALAYAH \\ A knowledge Repository
}

\title{
THE CORELATION OF RISK TOWARD PROFIT MARKETING LEVEL OF COCONUT PRODUCTS
}

\author{
Ine Fausayana *1, Weka Gusmiarty Abdullah ${ }^{\mathbf{1}}$, La Ode Dawid ${ }^{1}$ \\ ${ }^{1}$ Department of Agribusiness, Faculty of Agriculture. Halu Oleo University, Kendari, Southeast \\ Sulawesi Indonesia
}

\begin{abstract}
This study aims to analyze the correlation of risk with the marketing profit of coconut products in Kendari City This research uses qualitative and quantitative methods (deviation standard and probability). The populations of this research are all sellers of grated coconut, young coconut dan young coconut ice in Kendari City. Determination of sample for seller of coconut shredded using simple random sampling, while for seller of young coconut dan young coconut ice by using census. The results of this study are grated coconut products in the normal and surplus sales period have a medium risk level, and critical sales period has a high risk. Young coconut dan young coconut ice in normal and high sales periods have low risk, and in critical sales periods have a medium risk. The correlation of risk and the marketing profit level of coconut products is that high level of risk followed by a low marketing profit, conversely low risk level followed by high marketing profits.
\end{abstract}

Keywords: Coconut Products; Risk; Risk Level; Risk Probability

Cite This Article: Ine Fausayana, Weka Gusmiarty Abdullah, and La Ode Dawid (2018). "THE CORELATION OF RISK TOWARD PROFIT MARKETING LEVEL OF COCONUT PRODUCTS." International Journal of Research - Granthaalayah, 6(8), 172-178. https://doi.org/10.29121/granthaalayah.v6.i8.2018.1421.

\section{Introduction}

Agriculture is a unique sector because of its dependence on the climate and biological variables. Therefore, in agriculture it is vital to identify and evaluate risks to be sure that decisions made on the farm will bring positive results (Girdžiūte, 2012; Ulla R et al, 2016; Fausayana I et al., 2017). Risk implies a change of loss, possibility of loss, uncertainty, the actual spread of expected results, or the probability of a different outcome than expected (Wulandari and Wahyudi, 2014).

Research on risk has been frequently conducted in several places. Broll et al (2013) in his study entitled Risk Price and Risk Management in Agriculture concludes that Farmers face various sources of price uncertainty and that the farmer's optimal commodity futures market position, i.e., a cross-hedge strategy, is actually an over-hedge, a full-hedge, or an under-hedge strategy, depending on whether the two prices are strongly positively correlated, uncorrelated, or negatively 
correlated, respectively. The result of this research is supported by Makki SS (2001) that Price uncertainty generated by consumer concerns is the major risk facing biotech farmers.

The same study was conducted by Sanghyo Kim, MS (2015), the study finding implies that the choice of hedged and unhedged storage depends on the risk-return preference of the storage agent. In particular, if farmers prefer higher net return on lower risk, these farmers prefer hedging with futures contracts. The review of commodity futures markets was undertaken by Carter CA (1999), but he argued that the literature has failed to explain the prevalence of inverted markets in grains and oilseeds, and there is unexplainable price volatility in markets.

\section{Research Methods}

\section{Location and Time of Study}

This research was conducted in Kendari City. The location of research was purposively determined in consideration that Kendari City is the capital of Southeast Sulawesi province (Sultra) which is the center of economic and governmental activity of Southeast Sulawesi. This study was conducted on March to December 2015.

\section{Population and Sample}

The population referred to in this study are all sellers of grated coconut, young coconut seller and young coconut ice seller located in Kendari City. The number of population in this study according to the results of the initial survey is a number of 143 sellers, namely 110 sellers of grated coconut, 15 sellers of young coconut, and 18 sellers of young coconut ice.

\section{Types and Data Sources}

The types of data used in this study are qualitative data and quantitative data. Qualitative data is data in the form of sentence, word or picture (Sugiyono, 2013). Qualitative data in the form of description of words or sentences containing information from the seller regarding marketing activities related to technical risk aspects. Quantitative data consists of discrete data and continuum data.

Discrete data in the form of data obtained from the calculation or counting various events in the marketing of coconut products made by the seller. This data consists of nominal data used for data of dummy variables, such as coconut quality data, number of purchase transactions. Continuum data in the form of data obtained from the measurement results. This data consists of interval data and ratio data. Sources of data in this study are primary data and secondary data. Data collection techniques were conducted through surveys and in-depth interviews with a questionnaire guide to obtain risk information faced by sellers of grated coconut, young coconut seller, and young coconut ice seller.

\section{Research Variable}

The variables observed in this study are marketing risks (risk coefficients and risk opportunities); the purchase price of coconut products; the selling price of coconut products; production cost; marketing acceptance; marketing profit; frequency of purchasing transaction of raw materials; coconut products' selling frequency; marketing barriers; loss of marketing; and characteristics of 
respondents (age, education, length of business and number of family dependents) from the marketing of grated coconut, young coconut and young coconut ice.

\section{Data Analysis}

Problems were analyzed by using standard deviation approach and probability approach. The marketing profit of coconut products is calculated using the formula (Sunyoto, 2011): The average of marketing profit is calculated using the mean formula (Sugiyono, 2013). There are 5 (five) risk levels for each measurement result of risk coefficient percentage as shown in Table 1.

Table 1: Risk Levels by Risk Coefficients (Rs)

\begin{tabular}{|l|l|}
\hline Risk Level & Rs Value $(\%)$ \\
\hline Very high & $81,01-100,00$ \\
High & $61,01-80,00$ \\
Medium & $41,01-60,00$ \\
Low & $21,01-40,00$ \\
Very Low & $0,00-20,00$ \\
\hline
\end{tabular}

The correlation of risk and marketing profit are assessed based on the effect of risk level with the average of marketing profit. The correlation of risk and marketing profits are said to be positive if high risk levels are followed by high average of profit. The correlations are said to be negative if the risk level is followed by a low average of profit or low risk level followed by a high average of profit.

\section{Results and Discussion}

Sustainability in the marketing of coconut products is largely determined by the problems and constraints that constitute business risks in marketing. The types of risks that have been identified in the marketing of the previous coconut products must be known in size for further knowing its risk factors. Information on the level of marketing risk is required for risk reduction which further can increase the marketing profits of coconut products.

\section{Marketing of Grated Coconut}

The marketing of grated coconut is part of the coconut product marketing system. The existence of limiting factors of climate and weather and socio-cultural conditions make the marketing of grated coconut has three sales periods in a year. The sales period of grated coconut is differentiated based on the level of demand and profit of the marketing of grated coconut. This suggests a risk in the marketing of grated coconut. The level of marketing risk of grated coconut can be clearly seen in Table 2.

Table 2: Risk Level on Grated Coconut Marketing Based on its Sales Period in Kendari City

\begin{tabular}{|l|l|l|l|}
\hline & Normal & Surplus & Critical \\
\hline Average of Profits (USD) & 88 & 107 & 34 \\
\hline Variance & 252.203 .703 .762 & 511.470 .791 .538 & 82.792 .944 .526 \\
\hline Standard Deviation & 502.199 & 715.172 & 287.738 \\
\hline Risk Coefficient & 0,42 & 0,48 & 0,62 \\
\hline \% Rs & 41,54 & 48,37 & 61,78 \\
\hline
\end{tabular}




\begin{tabular}{|l|l|l|l|}
\hline Risk Level & Medium & Medium & High \\
\hline
\end{tabular}

Table 2 shows that the biggest marketing risk in the marketing of grated coconut is the risk in the critical sales period with the percentage of risk coefficient at $61.78 \%$ which is in the high category (interval value Rs $60.01-80.00 \%$ ). The high-risk period of critical sales is shaped by the standard value of deviation ratio of 287,738 and the average of selling profit in the critical period with USD 34. The risk level in the normal sales period is $41.54 \%$ which is in the medium category. The smallest marketing risk of grated coconut is the risk in the surplus sales period with the percentage of risk coefficient at $48.37 \%$ which is in the medium category (Rs $40.01-60.00 \%$ ). Medium risk level in the surplus sales period is formed by low risk coefficient value, that is 0.48 .

\section{Coconut Ice Marketing}

young coconut ice marketing has diverse risks in each sales period. The most economically conspicuous risk of young coconut ice marketing is profit risk. Profit risks have a calculated opportunity. The risk level of marketing gain is related to the vulnerable or variation of profit from any marketing profit of young coconut ice. The level of marketing risk of young coconut ice in each sales period can be seen in Table 3 .

Table 3: Marketing Risk of young coconut ice Based on Sales Period in Kendari City

\begin{tabular}{|l|l|l|l|}
\hline & Normal & Surplus & Critical \\
\hline Average Profits (USD) & 83 & 135 & 59 \\
\hline Variance & 156.012 .313 .208 & 181.968 .226 .253 & $153.270 .427 .675,79$ \\
\hline Standard Deviation & 394.984 & 426.577 & 391.498 \\
\hline Risk Coeficient & 0,35 & 0,23 & 0,48 \\
\hline \% Rs & 34,68 & 22,90 & 48,31 \\
\hline Risk Level & Low & Low & Medium \\
\hline
\end{tabular}

Table 3 shows that the biggest risk to young coconut ice marketing is in the critical sales period with a risk coefficient at a percentage of $48.31 \%$ which is in the high category (Rs $40.01-60.00 \%$ ). The high-risk level comes from the standard deviation ratio and the high average of profit gained (risk coefficient) compared to other sales periods. The smallest risk level is in the surplus sales period with the percentage of coefficient of risk at $22.90 \%$ which is in the medium category (Rs interval value $20.01-40.00 \%$ ). The low risk level of the sales period stems from a low risk coefficient ratio. Normal sales period has medium risk level with value of risk coefficient percentage at 34,68\% (interval value Rs $20,01-40,00 \%$ ).

\section{Young Coconut Marketing}

Variations in price and quantity of supply on the marketing of young coconut form an average of various profits so that the selling period has a varying degree of risks. The diversity of risk levels comes from the varying values of the standard deviation ratio and the average profit of marketing. Standard deviations show the range of data variations from the profitability of young coconut sales. Young coconut marketing risk level based on sales period clearly can be seen in Table 4 . 
Table 4: Young coconut Marketing Risk Based on Sales Period in Kendari City

\begin{tabular}{|l|l|l|l|}
\hline & Normal & Surplus & critical \\
\hline Average of Profits (USD) & 108 & 265 & 45 \\
\hline Variance & 216.269 .791 .701 & 939.993 .318 .836 & 94.433 .439 .408 \\
\hline Standard Deviation & 465.048 & 969.533 & 307.300 \\
\hline Risk Coefficient & 0,31 & 0,26 & 0,50 \\
\hline$\%$ Rs & 31,18 & 26,51 & 49,83 \\
\hline Risk Level & Low & Low & Medium \\
\hline
\end{tabular}

Table 4 shows that the bigest risk to young coconut sales is in the critical sales period with the risk coefficient of $49.83 \%$ which is in the medium category (Rs $40.01-60.00 \%$ ). This medium risk level has a low variance with a value of 94.433.439.408, compared to other sales periods. The smallest risk level is in the period of surplus sales with the percentage of risk coefficient at $26.51 \%$ which is the in low category (interval value Rs $21,01-40,00 \%$ ). The low risk level in the surplus sales period has a high standard deviation value compared to other sales period, which is 969.533 . The normal sales period has a low risk level with a percentage coefficient of risk at $31.18 \%$ (interval value Rs $21.01-40.00 \%$ ).

The results of marketing risk level analysis show that marketing risk of grated coconut products is in medium and high category, the risk of young coconut and young coconut ice are in low and medium category.

\section{The Correlation of Risk Toward Marketing Profit of Coconut Products}

Risks in the marketing of coconut products are focused on the risks of profit under normal circumstances that pose a threat of harm. Profit risks appear due to the large marketing costs incurred and the low income of sellers of coconut products. The amount of costs incurred for production costs in marketing is influenced by the level of demand for coconut products. The state of a dynamic marketing environment influences the level of demand and supply

The risks to marketing profits based on the type of coconut products and their sales period can be seen in Table 5.

Table 5: Average of Profit and Marketing Risk of Coconut Product in Kendari City

\begin{tabular}{|l|l|l|l|l|}
\hline Coconut Products & Selling Period & Average of Profit (USD) & Rs (\%) & Risk Level \\
\hline Grated coconut & Normal & 88 & 41,54 & Medium \\
\cline { 2 - 5 } & Surplus & 107 & 48,37 & Medium \\
\cline { 2 - 5 } & Critical & 34 & 61,78 & High \\
\hline \multirow{3}{*}{ young coconut ice } & Normal & 83 & 34,68 & Low \\
\cline { 2 - 5 } & Surplus & 135 & 22,90 & Low \\
\cline { 2 - 6 } & Critical & 59 & 48,31 & Medium \\
\hline Young coconut & Normal & 108 & 31,18 & Low \\
\cline { 2 - 6 } & Surplus & 265 & 26,51 & Low \\
\cline { 2 - 5 } & Critical & 45 & 49,83 & Medium \\
\hline
\end{tabular}

Table 5 shows that the highest level of risk lies in the product of grated coconut during the critical sales period, it is $61.78 \%$ with the lowest average marketing profit at US\$ 34 . This shows that the 
marketing of grated coconut in the critical selling period has a higher chance of loss compared to other coconut products. The risk level is being faced in the normal sales period with Rs (\%) of $41.54 \%$ and the average profit is USD 88 . The marketing of grated coconut during the surplus sales period is in the medium risk level with Rs (\%) of $48.37 \%$ and the average profit is USD 107. When it is compared to the level of risk based on the type of coconut products marketed, grated coconut products have a higher risk level compared to other coconut products (young coconut and young coconut ice). Higher risk levels are due to the large variation in profits from the sale of grated coconut. Large profit variations also provide hope for high profit gains. High profit expectations are followed by a relatively high level of risk.

The marketing of coconut products with the lowest risk level is the marketing of coconut ice product in the surplus sales period, which is $22.90 \%$ with the highest average profit value at USD 135. Low risk level with high average of income allows for the sustainability of young coconut ice marketing. Low risk level on the sales of young coconut ice is also in the normal sales period at $34.68 \%$ with an average profit at USD 83. The critical sales period has a medium risk level of $48.31 \%$ with an average profit at USD 59. When it is viewed on the basis of the percentage level of risk, young coconut ice marketing has a lower Rs (\%) (risk level) score compared to the marketing of grated coconut in all sales and young coconut in the surplus and critical periods, although at the average profit per period its sales do not give lower value as well.

The marketing of coconut products with the lowest risk level in the normal sales period is found in young coconut products with $31.18 \%$ which is at medium risk level. This sales period has a higher average profit compared to grated coconut and coconut ice products in the same sales period, which is worth USD 108. Young coconut marketing in the surplus sales period also has a low risk level at $26.51 \%$, while in the critical sales period it has a medum risk level with $49.83 \%$ which indicates a higher percentage. The average profit value in the surplus sales period is USD 265, while the average profit value in the critical sales period is USD 45 which shows lower value. Variations in the coconut marketing profit and the high level of marketing risk of coconut products are also caused by the socio-cultural condition of coconut product marketing businessmen and the society in general. This is in accordance with previous research that consumer purchasing decisions are strongly influenced by socio-cultural factors (Suprayitno et al, 2015; Dumas Y, 2014; Lawan and Zanna, 2015; Akpan and John S. 2016).

The biggest risk affecting the marketing of coconut products is the risk caused by the institutional and partnership circumstances. Marketing of coconut products that have no legal guarantees either on the partnership contract or legal recognition of the trading business undertaken.

\section{Conclusion}

Product of grated coconut has medium risk level in normal and surplus sales periods and high risk at critical sales period. Products of young coconut ice and product of young coconut have low risk level in normal and surplus sales periods and medium risk level at minimum sales period. The correlation of risk level and marketing profit of coconut products is that the high risk is followed by low marketing profit, conversely increases of risk level followed by high marketing profit. 


\section{References}

[1] Akpan and John S. 2016. The Influence of Cultural Factors on Consumer Buying Behaviour (A Case Study of Pork). British Journal of Marketing Studies Vol.4 (6): 44-57.

[2] Broll U, Welzel P. Wong KP. 2013. Risk Price and Risk Management in Agriculture. Contemporary Economics Vol. 7 (2): 17-20. DOI: 10.5709/ce.1897-9254.79.

[3] Carter CA. 1999. Commodity futures markets: a survey. The Australian Journal of Agricultural and Resource Economics. Vol 43 (2): 209-247.

[4] Dumaz Y. 2014. The Influence of Cultural Factors on Consumer Buying Behaviour and an Application in Turkey, Global Journal of Management and Business Research: E Marketing Vol 14 (1): $36-44$.

[5] Fausayana I., Abdullah WG., Susanti F., Sidu D., Arimbawa., Yunus L. 2017. Factors Affecting the Behavior of Farmers Toward the Risk of Seaweed Farming in the Bungin Permai Village, Southeast Sulawesi, Indonesia. AACL Bioflux, 2017, Vol 10 (6) : 1647-1653

[6] Girdžiūtè. 2012. Risks in Agriculture and Opportunities of their Integrated Evaluation. ProcediaSocial and Behavioral Sciences. Volume 62 : 783-790. https://doi.org/10.1016/j.sbspro.2012.09.132.

[7] Lawan LA., Zanna R. 2013, Evaluation of Socio-Cultural Factors Influencing Consumer Buying Behaviour of Clothes in Borno State, Nigeria. International Journal of Basic and Applied Science, Vol 1(3): 519-529

[8] Makki SS., Somwaru A., Harwood J. 2001. Biotechnology in Agriculture: Implications for FarmLevel Risk Management. Journal of Agribusiness 19 (1): 51-67.

[9] Sanghyo Kim, MS, 2015. Analysis of Agricultural Commodity Storage Using Futures and Options Market. Dissertation. Graduate Program in Agricultural, Environmental and Development Economics. The Ohio State University. Pp 120.

[10] Sugiyono. 2013. Statistika untuk Peneliti. Alfabeta. Bandung.

[11] Sunyoto, D. 2011. Matematika Ekonomi dan Bisnis (Teori, Soal Latihan, dan Soal Jawaban). Yogyakarta: Center for Academic Publishing Service (CAPS).

[12] Suprayitno A., Rochaeni., Purnomowati R. 2015. Pengaruh Faktor Budaya, Sosial, Pribadi, dan Psikologi Konsumen Terhadap Keputusan Pembelian Pada Restoran Gado-Gado Boplo (Studi Kasus: Restoran Gado-Gado Boplo Panglima Polim Jakarta Selatan). Jurnal Agribisnis. Vol. 9(2): $177-214$.

[13] Ullah R., Shivakoti GP., Zulfiqar F., Kamran MA. 2016. Farm risks and uncertainties. Sources, impacts and management. Sage Journals. Vol 45 (3): 199-205.

[14] Wulandari dan Wahyudi. 2014. Manajemen Resiko Dalam Pengembangan Pertanian Organik Di Indonesia. Prosiding Seminar Nasional Pertanian Organik Bogor 18 - 19 Juni 2014: 51-60.

*Corresponding author.

E-mail address: inefausayana@ymail.com/wkgusmiarty09@yahoo.com/dawidfarid@yahoo.co.id 